\title{
SUMMARY
}

\author{
PRELIMINARY OBSERVATIONS ON THE RELATIONSHIP \\ BETWEEN NUTRITION STATUS AND GENOTYPE IN GILTS
}

Fattening and carcass traits of 172 French Landrace $(L F)$, Belgian Landrace $(B L)$ and Pietrain $(P P)$ gilts were compared, in relation to nutritional variations, according to a factorial design $2 \times 3 \times 2 \times 2$ : two replicates, three breeds, two dietary digestible energy levels 3.0 and $3.3 \mathrm{Mcal} \mathrm{DE} / \mathrm{kg}$, respectively, two ratios of crude protein to digestible energy ( 52 and $66 \mathrm{~g}$ crude protein per Mcal DE, respectively). The composition of diets was maintained constant during the total test period $(27$ to $96 \mathrm{~kg})$ and they were offered ad libitum. The mean values of $F L, B L$ and $P P$ pigs for average gain (g), daily food consumption (kg) and food conversion ratio $(\mathrm{kg}$ food $/ \mathrm{kg}$ gain) were $: 7 \mathrm{I} 8,689,559 ; 2.33,2.15, \mathrm{I} .88 ; 3.27,3.14,3.4 \mathrm{I}$, respectively. The $B L$ and $P P$ pigs did not differ in most of the carcass traits, but both were markedly superior to $F L$ pigs in dressing percentage and criteria of carcass composition. Whatever the breed, no significant influence of an increase in the energy content of the diet was observed on growth rate and food conversion ratio expressed as digestible energy/ $\mathrm{kg}$ gain (approximately $10.3 \mathrm{Mcal} \mathrm{DE} / \mathrm{kg}$ gain). Data of specific gravity indicate that carcasses from pigs fed the high digestible energy diets were fatter. However, a pig breed $x$ dietary energy interaction was found for some carcass traits, particularly weight and specific gravity of the ham ; increasing the dietary energy content resulted in a higher fatness with $F I$. pigs, while it had no effect on $B L$ pigs and it was rather favourable with $P P$ pigs. Increase in the protein content of the diet had a significantly unfavourable influence on growth rate and food conversion during the finishing period (50 to $96 \mathrm{~kg}$ ) ; for the latter trait, this infuence occured only in $F L$ and $P P$ pigs. It is suggested that the Belgian Landrace pigs, with a fast muscle growth, are the most able to utilize diets with a higher protein level.

\section{RÉFÉRENCE DE COMPOSITION ANATOMIQUE ET CRITÈRES DE CLASSIFICATION DES CARCASSES DES PORCS FEMELLES DES TYPES « LANDRACE FRANÇAIS " « LANDRACE BELgE " ET « PIÉTHAIN"}

\section{B. DESMOULIN et P. POMMERET}

Station de Recherches sur l'Élevage des Porcs, Centre national de Recherches zootechniques, $I, N . R$. A., 78350 Jouy en Josas

Institut Technique du Porc

149, Rue de Bercy,

75579 Paris Cedex 12

\section{RÉSUMÉ}

Cent soixante et une carcasses de porcs femelles des 3 types génétiques : Landrace Français, Landrace Belge et Piétrain, ont été soumises aux méthodes usuelles de l'appréciation qualitative (épaisseurs du lard dorsal, poids des morceaux de découpe) puis aux déterminations de la densité corporelle. 
Par ailleurs, 48 carcasses de cet échantillon ont été disséquées pour référencer la composition tissulaire et la variation des rapports $\frac{\text { muscles }}{\text { graisses }}$ et $\frac{\text { muscles }}{\text { os }}$ en fonction de la race et des conditions nutritionnelles.

Les résultats concernent les références de composition anatomique et les critères de classification des carcasses.

Io La réduction du rapport $\frac{\text { muscles }}{\text { graisses }}\left(M / G=I, 5^{8}\right)$ est plus accentuée chez les Porcs Landrace Français qui sont nourris à volonté de régimes Maïs/Soja, riches en énergie. L'augmentation du rapport $\frac{\text { muscles }}{\text { graisses }}(\mathrm{M} / \mathrm{G}$ de 2,66 à 3,05) est plus importante chez les Porcs Landrace Belge qui reçoivent des rations à haute teneur en protéines. Les caractéristiques tissulaires des Porcs Piétrain (M/G de 2, I à 2,5) semblent plus indifférentes aux conditions nutritionnelles. Les besoins de la musculature hypertrophiée à croissance rapide chez le Porc Belge ou à croissance lente chez le Porc Piétrain, sont ainsi différenciés.

$2^{0}$ Les gammes de composition anatomique sont établies pour chaque race en fonction des index de densité de l'ensemble "Longe + Bardière " ou "Rein de Porc ". La variation quantitative du rapport $\frac{\text { muscles }}{\text { graisses }}$ 'établit entre les valeurs $I, 3$ et 2,6 pour le type Landrace Français entre I,8 et 3,4 pour le type Landrace Belge et entre 1,9 et 3,2 pour le type Piétrain ; 7 classes de densité corporelle comprises entre les valeurs moyennes I 030-I 060-I 065 permettent de caractériser l'ensemble des gammes de composition tissulaire. La variation du rapport $\frac{\text { muscles }}{\text { os }}$ entre races entraîne simultanément une dérive de la classification suivant le rapport $\frac{\text { muscles }}{\text { graisses }}$ par les Index de densité. Dans la gamme des carcasses des types IA et EAA, les difficultés de l'appréciation du rendement en viande concernent la recherche des critères quantitatifs qui permettent de pallier les imprécisions des jugements de conformation. Comparativement aux résultats de SснӧN (1973), la gamme des porcs à viandes maigres entre les classes IA (rapport $\frac{\text { muscles }}{\text { graisses }}: 2, \mathbf{r}$ ) et EAA (rapport $\frac{\text { muscles }}{\text { graisses }}$ de 3,0 ou plus) laisserait place à une catégorie intermédiaire pour laquelle le rapport $\frac{\text { Muscles }}{\text { graisses }}$ est voisin de 2,6 dans les différentes populations étudiées.

\section{SUMMARY}

\section{THE ANATOMICAL COMPOSITION AS A REFERENCE VALUE FOR GRADING FEMALE PIG CARCASSES OF THE BREEDS : FRENCH LANDRACE, BELGIAN LANDRACE AND PIÉTRAIN}

One hundred and sixty one female pig carcasses of 3 genetic types: French Landrace, Belgian Landrace, Pietrain, were submitted to the usual methods of qualitative estimation (back fat thickness, weight of primal cuts).

In addition, $4^{8}$ carcasses of this sample were cut in order to establish the reference value of the tissue composition and of the variation in the $\frac{\text { lean }}{\text { fat }}$ and $\frac{\text { lean }}{\text { bone }}$ ratios according to the breed and nutritional conditions. 
The results concern the reference values of the anatomical composition and the carcass grading criteria.

I $^{0}$ The reduction of the $\frac{\text { lean }}{\text { fat }}\left(\mathrm{L} / \mathrm{F}=\mathrm{I}, 5^{8}\right)$ ratio was more marked in the French Landrace Pigs which were fed ad libitum highly energetic maize/soyabean diets. The increase in the $\frac{\text { lean }}{\text { fat }}$ ratio (L/F from 2.66 to 3.05 ) was greater in the Belgian Landrace pigs which received high protein diets. The tissular characteristics of the Pietrain pigs (L/F from 2.1 to 2.5) did not seem to depend much on the nutritional conditions. The requirements of the hypertrophied rapid growing musculature in the Belgian pig or slowly growing musculature in the Pietrain pig are thus differenciated.

$2^{\circ}$ The anatomical composition scales were established for each breed according to the specific gravity index of "Loin + Backfat" (or "Rein de Porc»). The quantitative variation of

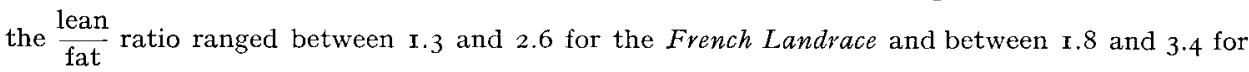
the Belgian Landrace and between 1.9 and 3.2 for the Pietrain breed; 7 grades of specific gravity comprised between the mean values of I 030-I 035 and I 060-I 065 allowed to characterize all the scales of tissular composition. Variation between breeds in the lean bone ratio led simultaneously to a deviation of the evaluation of $\frac{\text { lean }}{\text { fat }}$ ratios by the specific gravity determi nations.

As regards the carcasses of the types IA and EAA, the estimation of lean mass yield needs searching for quantitative criteria allowing to palliate the lack of accuracy in the judgments of conformation. In comparison with the results of ScHöN, (I973), the scales of lean pigs between the classes IA $\left(\frac{\text { lean }}{\text { fat }}\right.$ ratio : 2.1$)$ and EAA $\left(\frac{\text { lean }}{\text { fat }}\right.$ ratio : 3.0$)$ permit an intermediate grade with a $\frac{\text { lean }}{\text { fat }}$ ratio close to 2.6 to be proposed in the different populations studied.

\title{
PROPIRIÉTÉS SENSORIELLES \\ ET QUALITÉS TECHNOLOGIQUES DE LA VIANDE \\ DE TROIS RACES DE PORCS \\ ( LANIRACE BELGE ", " LANDRACE FRANÇAIS " ET « PIÉTRAIN »)
}

\author{
B. L. DUMONT \\ Laboratoire de Recherches sur la Viande, \\ Centre national de Recherches zootechniques, $I . N, R, A$., \\ 78350 Jouy en Josas
}

\section{RÉSUMÉ}

On a étudié les propriétés sensorielles (qualités de dégustation) et les caractéristiques physiques de la viande de femelles de trois races de porcs (Landrace Belge (LB), Landrace Français $(L F)$ et Piétrain $(P))$ abattues à $95 \mathrm{~kg}$ de poids vif environ. 